Helgoländer wiss. Meeresunters. 17, 247-256 (1968)

\title{
Progress report on a programme of insecticide analysis and toxicity-testing in relation to the marine environment
}

\author{
John E. Portmann \\ Ministry of Agriculture, Fisheries and Food, \\ Fisheries Laboratory, Burnham-on-Crouch, Essex, England
}

KURZFASSUNG: Fortschrittsbericht über ein Arbeitsprogramm der Insektizidanalyse und der Toxizitätsprüfung in bezug auf die marine Umwelt. Seit 1965 läuft im Fischereilaboratorium von Burnham-on-Crouch ein Arbeitsprogramm zur Prüfung der Toxizität verschiedener chemischer Stoffe gegenüber Meerestieren. Die Konzentration chlorhaltiger Insektizide in Meeresfischen und Schalentieren wurde untersucht und die Toxizität von Metallen und von Phenol gegenuiber drei Crustaceenarten und einer Molluskenart ermittelt. Ferner wurde der Einfluß der Temperatur, der Tiergröße und des Nahrungsangebotes auf die Toxizität geprüft. Eine Reihe von Detergentien wurde ebenfalls hinsichtlich toxischer Wirkungen untersucht. Die Konzentrationen von drei verschiedenen Insektiziden wurden in der Muskulatur und in der Leber des Kabeljaus (Gadus morbua) bestimmt.

\section{INTRODUCTION}

In 1965, work was commenced at our laboratory on the effects of pollution on inshore fisheries. It at once became apparent that, although considerable information is available regarding the toxicity of various pollutants to freshwater life, there is little on the toxicity of pollutants to marine life.

The term "chemical pollutant" covers a multitude of materials but these can be loosely divided into the following categories: inorganic and organic trade wastes, detergents, oils, radioactive wastes, and pesticides. Because many trade wastes contain quantities of heavy metals, and domestic sewage contains detergents, it was decided to examine the toxicity of these groups of compounds to a number of marine animals. In recent years pesticides have been the cause of increasing alarm, and it is intended to examine the toxic effects of these materials in due course; however, at the present time this problem is being approached from a different angle, and analysis of shellfish and fish specimens for organo-chlorine pesticides is well under way. Details of the early results of our toxicity tests and of our pesticide analyses are presented in this paper.

Although there are a number of advantages in using a continuous flow toxicitytesting system it was decided to use a static system. Figure 1 shows one of our two 
toxicity-testing arrangements, each consisting of 15 perspex tanks in three tiers. Perspex was used because it was easy to wipe clean and because, if necessary, acids and solvents such as acetone could be used without damage to the interior surfaces. Each tank held 10 litres of sea-water and was provided with an aerator and a sloping splash guard to minimize the interchange of different pollutant concentrations by the aerator spray. A variety of marine animals were used in the tests, but the chief ones were the pink shrimp (Pandalus montagui), brown shrimp (Crangon crangon), shore crab (Carcinus maenas), and cockle (Cardium edule); 25 animals were normally held in each tank during an experiment. For each experiment a control was run, with a different test species, to guard against erroneous results; for example due to failure of the air supply.

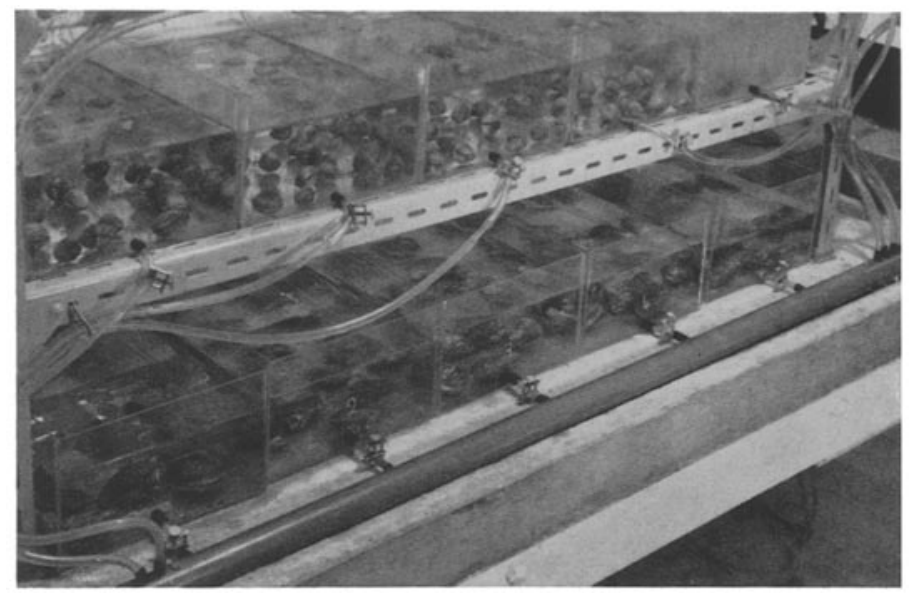

Fig. 1: Toxicity-testing apparatus

The test animals, which had been acclimatized to laboratory conditions for at least 3 days, were placed in sea-water to which toxin solutions at a range of concentrations had been added, and left for 48 hours, this being the standard experimental period. All the experiments were conducted in the dark in rooms in which the air temperature was controlled, and tanks containing mobile animals were covered with a plastic mesh to prevent escapes. The tanks were examined at intervals during the course of the experiments and animals which had died were removed, the total number dead after 48 hours being recorded. The results are all expressed in terms of $L D_{50}$, this being the concentration required to kill $50 \%$ of the test animals; this value is readily obtained by graphical interpretation of the results.

\section{RESULTS AND DISCUSSION}

\section{Toxicity of metals and phenol}

Routine testing was done at $15^{\circ} \mathrm{C}$ which was taken as representative of inshore summer water temperatures. The results of a series of experiments conducted at this 
temperature, with four heavy metals and phenol, using the four test species mentioned above, are shown in Figures $2 a$ and $b$. It was found that with four out of the five chemicals the pink shrimp (Pandalus montagui) was the most susceptible species, and in the only exception the $\mathrm{LD}_{50}$ for Pandalus was very close to that for the most susceptible species. We have had only one other such exception in all the tests made to date with 36 different chemicals or mixtures. The order of tolerance after pink shrimps is not so clear, although the general one of brown shrimps, shore crabs and

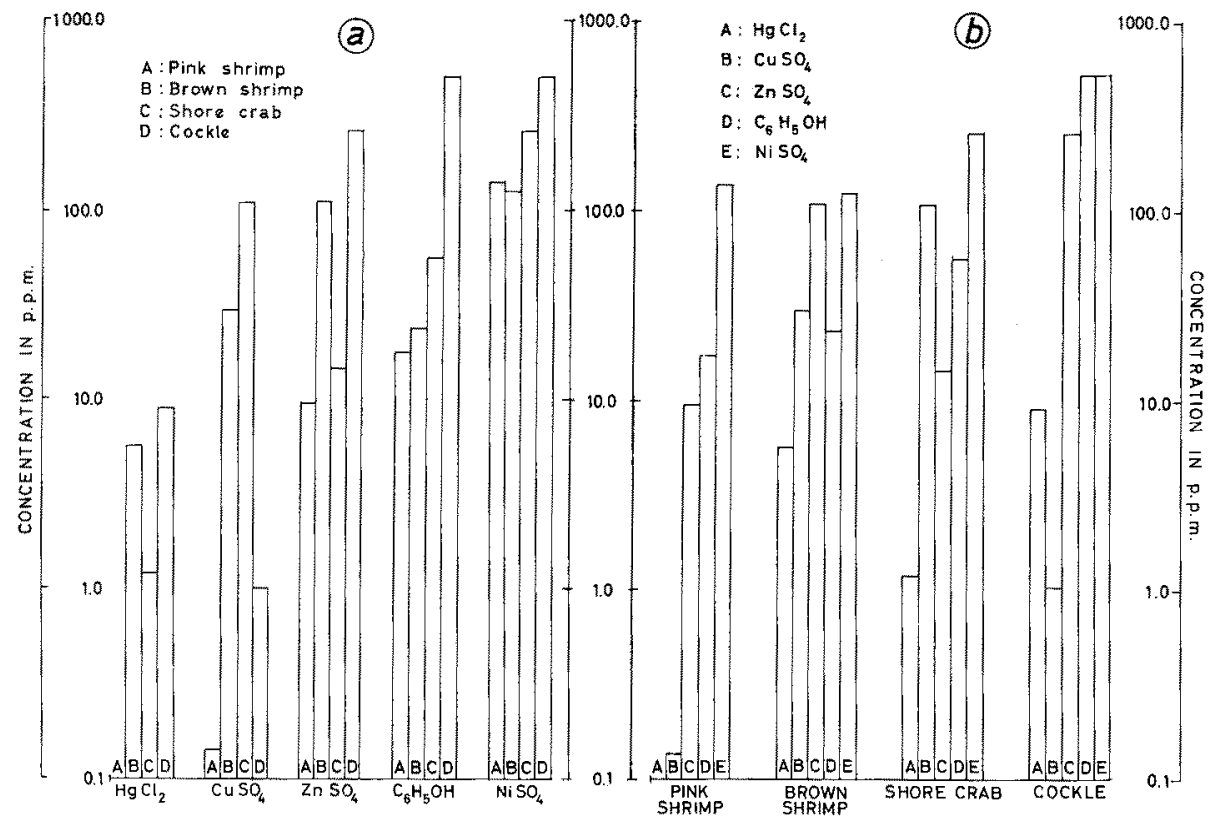

Fig. 2: Results of experiments using 4 heavy metals and phenol on pink shrimps, brown shrimps, shore crabs and cockles: (a) the order of susceptibility of the 4 test species; (b) the order of toxicity of the 5 solutions

cockles is illustrated in Figure $2 \mathrm{a}$. Two experiments with cockles were terminated when less than $50 \%$ mortality had occurred after 48 hours with concentrations up to 500 ppm; one experiment used phenol and the other nickel.

The relative toxicity of the five chemicals is shown in Figure $2 \mathrm{~b}$; the most toxic material was mercury, followed in order by copper, zinc, phenol and nickel. This sequence is interesting because it follows the relative solubilities of the four metals in sea-water. It is assumed that the metals act as enzymatic poisons, whereas phenol, being corrosive in nature, is assumed to act primarily upon the external surfaces.

\section{Effects of temperature on toxicity}

The effect of temperature on the $\mathrm{LD}_{50}$ is often not appreciated and some experiments with the selected toxins mercury, copper and phenol were conducted in order 
to examine this factor. These experiments were carried out using only two species, brown shrimps and cockles, but, as the results in Figures $3 \mathrm{a}$ and $\mathrm{b}$ show, the effect of temperature was very pronounced with both these animals. In fact a reduction in temperature from $22^{\circ}$ to $5^{\circ} \mathrm{C}$ was sufficient to increase the tolerance of brown shrimps

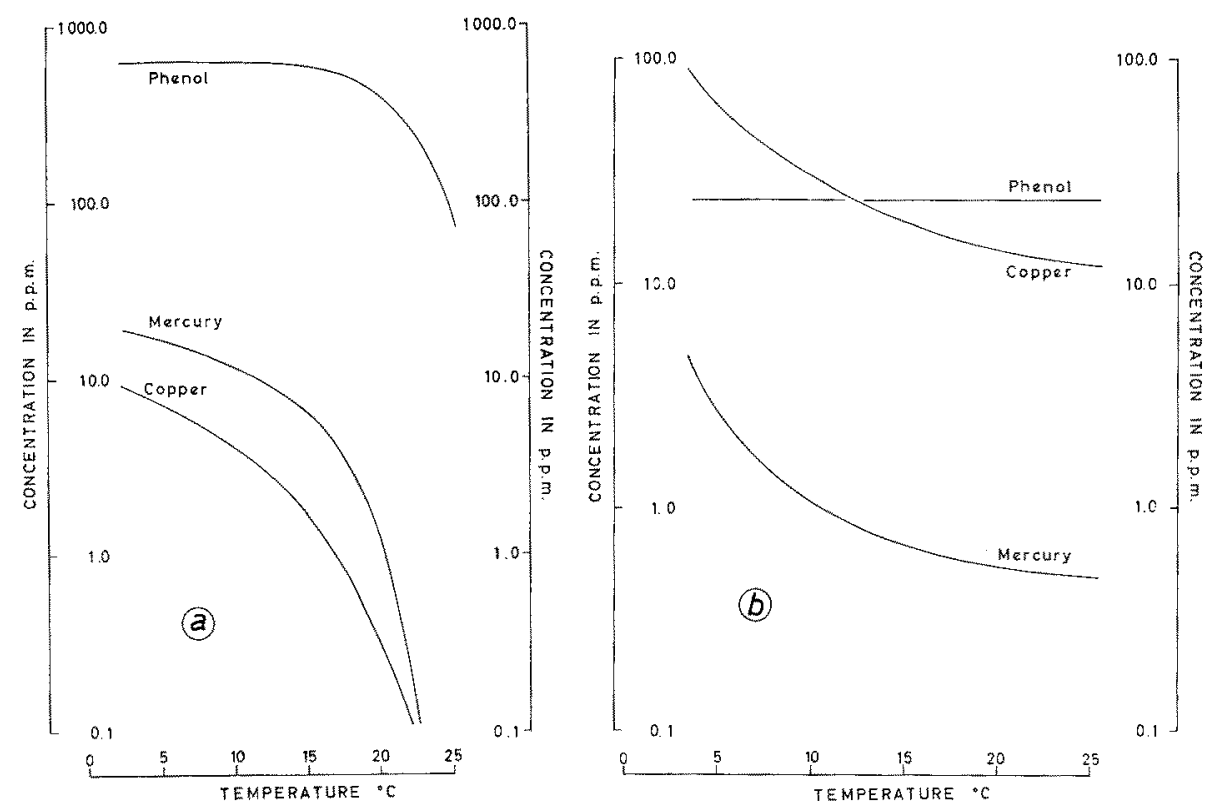

Fig. 3: Effect of temperature on the $\mathrm{LD}_{50}$ of mercury, copper and phenol on (a) cockles, (b) brown shrimps

to copper and mercury by a factor of 5, although with phenol there was no effect (Fig. 3b). With cockles the effect was even more pronounced, and a fall in temperature from $22^{\circ}$ to $5^{\circ} \mathrm{C}$ increased the $L D_{50}$ by factors of approximately 80 and 130 for copper and mercury respectively; there was also an effect on the $\mathrm{LD}_{50}$ for phenol on cockles, although the factor was only 2.4 .

There are undoubtedly many other factors which may influence the susceptibility of a species to a toxin, and two of the more likely ones are the age of the animals and whether or not they have been starved prior to the experiment; both of these factors were briefly examined.

\section{Effects of starvation on toxicity}

Feeding of cockles was rather difficult to ensure and it was therefore assumed that storage in slowly running aerated sea-water for two weeks was equivalent to partial starvation, whereas freshly collected cockles were assumed to be well fed. 
There was no such problem with shrimps and one batch was fed on chopped mussels whilst a second batch was starved. Both samples of cockles were collected from the same bed and both samples of shrimps came from the same catch.

Figure 4 shows the effect on the $\mathrm{LD}_{50}$ of using fed and unfed specimens of both cockles and brown shrimps for an experiment with mercury; in both instances starvation reduced the tolerance of the animals to the toxin. The $L D_{50}$ for brown shrimps

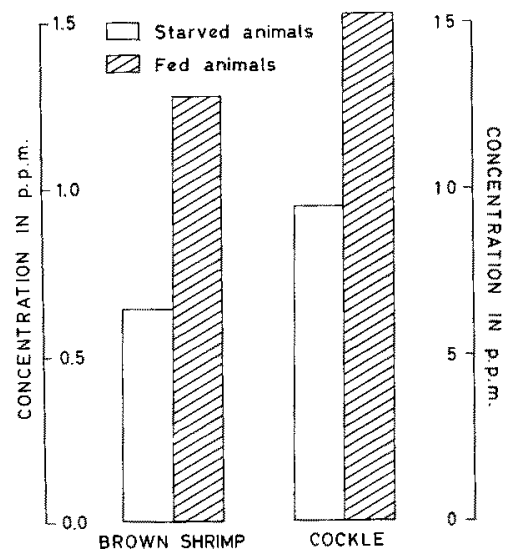

Fig. 4: Effect on the $\mathrm{LD}_{50}$ of mercury of feeding and not feeding brown shrimps and cockles prior to an experiment

was halved, falling from 1.3 to $0.65 \mathrm{ppm}$, whereas it was reduced by approximately one-third for cockles, falling from 15.5 to $9.6 \mathrm{ppm}$. If starvation is considered as a stress then these results are readily explained, since imposition of a stress in addition to the toxin might reasonably be expected to reduce the animals' resistance. Further experiments are needed on this topic before it can be said that results would always be so pronounced, but clearly starvation is a factor which must be considered.

\section{Effects of age of test animals on toxicity}

Figure 5 shows the effect on the $\mathrm{LD}_{50}$ of using markedly different size groups of brown shrimps in a test with mercury. Three different size groups were selected and it was found that the larger shrimps were the most resistant; the $\mathrm{LD}_{50}$ for this size was $1.26 \mathrm{ppm}$, more than double that for the smallest shrimps $(0.58 \mathrm{ppm})$. Again further work is necessary to determine whether or not this is the general pattern. It would also be interesting to compare these results with ones for a toxin such as phenol which has a different mode of action. It is perhaps worth noting that the dotted line shown in Figure 5 was used to predict the $\mathrm{LD}_{50}$ for the size group 1.5 to $2.5 \mathrm{~cm}$, with a considerable degree of success; the $\mathrm{LD}_{50}$ found by experiment was $0.48 \mathrm{ppm}$ and that predicted was $0.52 \mathrm{ppm}$. 


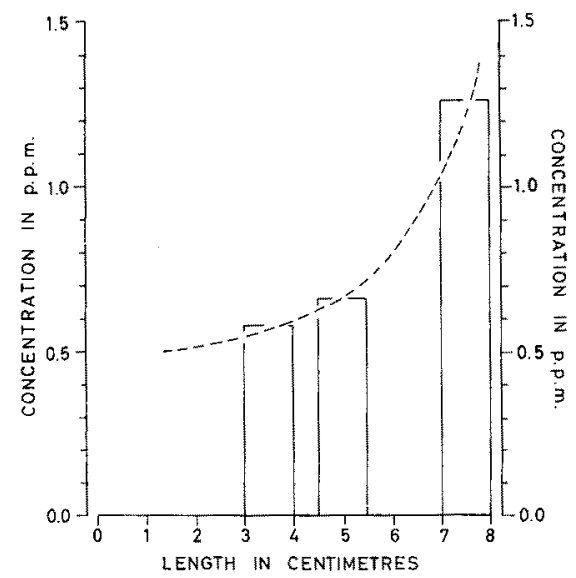

Fig. 5: Effect of the size of brown shrimps used in an experiment to determine the $\mathrm{LD}_{50}$ for mercury

\section{Toxicity of detergents}

When failures of specific fisheries occur around our coasts the cause is frequently attributed to the increasing quantity of detergents discharged into inshore waters. As there is no evidence on this question it was decided to examine the possibility of detergents being toxic to marine animals. It is only the surface active agents which are likely to be directly harmful to marine life and therefore only these compounds were
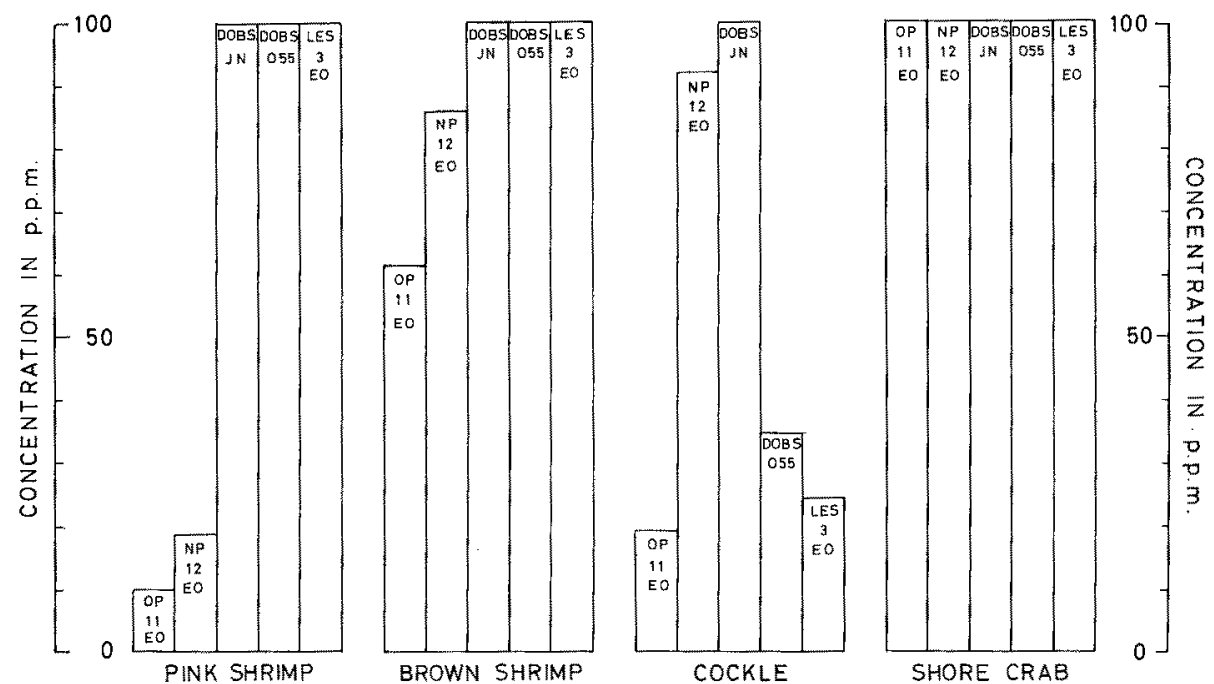

Fig. 6: Order of toxicity of five detergents to pink shrimps, brown shrimps, shore crabs and cockles 
examined, although detergent formulations contain large quantities of other materials (D.S.I.R. 1961). The standard toxicity tests were conducted using the four test species but the concentrations were limited to a maximum of $100 \mathrm{ppm}$ detergent. It is unlikely that anionic and non-ionic detergents in domestic sewage would be much in excess of 20. ppm and 2 ppm respectively (Ministry of Technology 1966), and this was felt to be a more than adequate limit. A number of different detergent compounds were tested but the main ones comprised 3 anionic detergents (Dobs JN, Dobs 055 and Lauryl Ether sulphate 3 Ethylene oxide) and 2 non-ionics (Octyl Phenol 11 Ethylene oxide and Nonyl Phenol 12 Ethylene oxide).

The results of the tests are shown in Figure 6 and indicate that at concentrations likely to be found in sewage effluents these detergents were not particularly harmful, at least to our adult test species. None of the detergents were used in concentrations above $100 \mathrm{ppm}$; for those cases where the $\mathrm{LD}_{50}$ was above the maximum concentration the figure shows the $\mathrm{LD}_{50}$ as being $100 \mathrm{ppm}$. The anionic detergents were generally found to be less toxic than the non-ionic detergents, and with only two exceptions the $\mathrm{LD}_{50} \mathrm{~s}$ were recorded as in excess of $100 \mathrm{ppm}$. $\mathrm{LD}_{50}$ values below $100 \mathrm{ppm}$ were recorded for eight of the tests with non-ionic detergents, and Octyl Phenol 11 Ethylene Oxide was found to be the more toxic of the two. This result is in agreement with work by MARCHETTI (1965), who found that an increase in the number of ethylene oxide molecules also increased the dose required to kill goldfish.

Although these results indicate that household detergents are unlikely to be a problem to adult animals in the marine field, the $\mathrm{LD}_{50}$ figures above $20 \mathrm{ppm}$ probably underestimate the toxicity because the use of aerators, which was unavoidable, resulted in foaming, particularly at the higher concentrations, and since the foam contains relatively much higher concentrations of detergent than the mother liquor (Moss 1958, TODD 1954) the concentration of detergent in the water must have been less than the nominal dose figure.

\section{Pesticide analysis}

The pesticide analysis programme at Burnham-on-Crouch consists of the analysis of fish and shellfish, collected both locally and from distant waters, for ten organochlorine insecticides, namely $\alpha, \beta$ and $\gamma \mathrm{BHC}$, heptachlor epoxide, aldrin, dieldrin, endrin, $\mathrm{Pp}$ ' DDT, DDE and TDE. For this work the preparation and clean-up method of DE Faubert Maunder et al. (1964) is used and a final sample volume of $1 \mathrm{ml}$ is achieved. Analysis of the $1 \mathrm{ml}$ concentrate is by gas liquid chromatography using a Varian Aerograph dual column, dual $\mathrm{E} / \mathrm{C}$ detector instrument with two recorders. The columns used are $5 \mathrm{ft} 1 / 8 \mathrm{in}$. O.D. pyrex glass and are packed with $2.5 \%$ SE 301 and $0.25 \%$ Epikote 1001 on 100/120 mesh Celite W and $2 \%$ Oronite polybutene 128 on 80/100 mesh Gas-Chrom Q respectively.

A selection of the results we have obtained is shown in Figure 7. These are the maximum and minimum concentrations of $\gamma$-BHC, DDT and dieldrin found in herrings (Clupea barengus), muscle and liver of cod (Gadus morbua), shrimps (Crangon crangon) and oysters (Ostrea edulis). As can be seen from this diagram there is a considerable range of concentrations of any one pesticide in a particular species. How- 
ever, it can be seen that the fish liver contains proportionately more pesticide than the muscle tissue. This would be expected as it is now well established that organo-chlorine compounds are stored in fatty tissues, and the result is in agreement with results published by other workers (HoLden 1966, RoBinson et al. 1967). Our highest pesticide residue to date has been for DDT in a whiting liver $(19.2 \mathrm{ppm})$ and generally we have found that livers from whiting (Merlangius merlangus) have the highest organo-chlorine pesticide content.
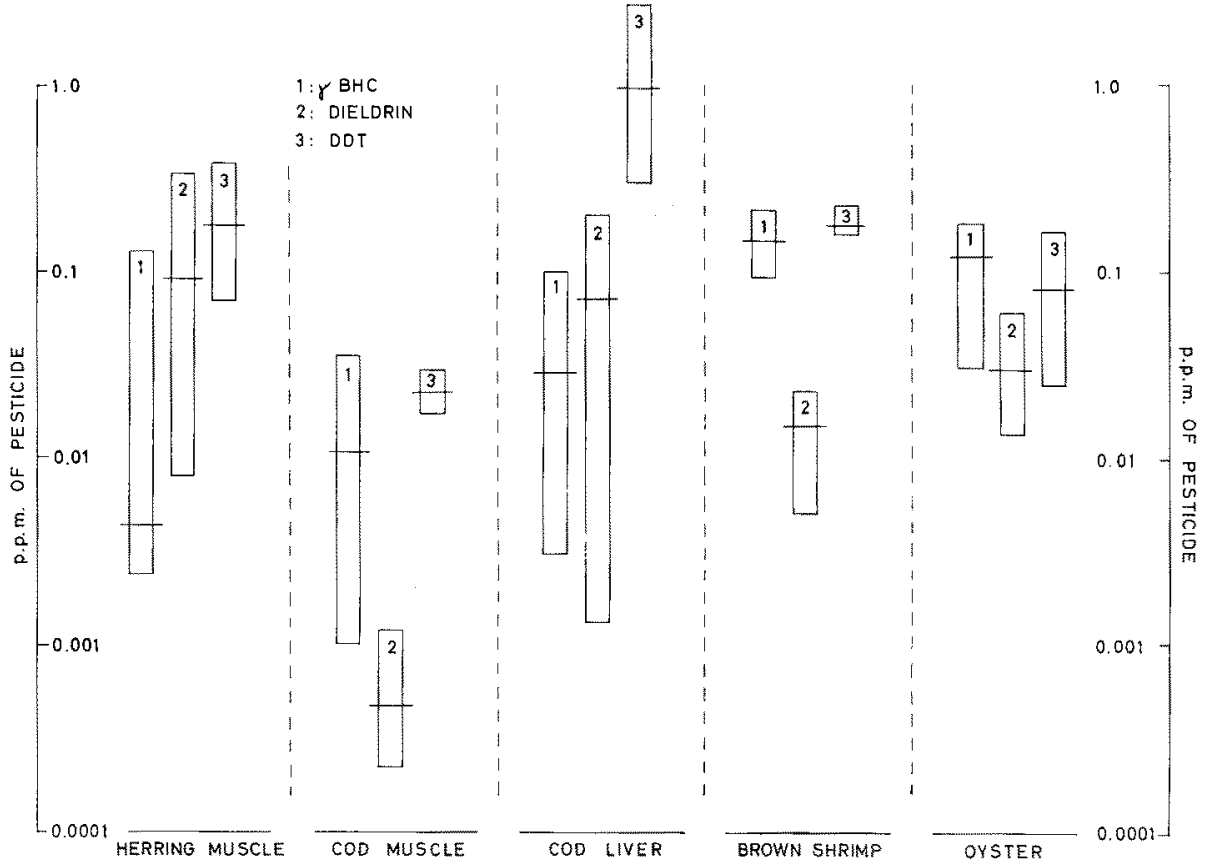

Fig. 7: Range and mean concentrations of $\gamma \mathrm{BHC}$ dieldrin and DDT found in some fish and shellfish

The results for oysters shown in Figure 7 were obtained in about March of 1967 and more recent results have been lower by a factor of ten. This suggests a possibility of seasonal variation, and work is now in progress on the analysis of regular oyster samples in an attempt to test this. As work by ButLer (1966) has shown, such a variation might reasonably be expected, since the oyster's environment will be subjected to seasonal variations in concentrations of pesticides according to their usage in agriculture.

\section{SUMMARY}

1. Toxicity experiments with 4 metals and phenol on Pandalus montagui, Crangon crangon, Carcinus maenas and Cardium edule are described and the results presented. 
2. Increase in temperature was found to cause a marked increase in the toxicity of some chemicals.

3. The larger-size animals were shown to be less susceptible to mercury.

4. Starvation of animals prior to experiments was demonstrated to reduce their tolerance to mercury.

5. The toxicity of a number of detergents to the 4 test species is described.

6. Results of pesticide analyses are given in terms of ranges and mean concentrations found in muscle tissue from 2 species of fish, the liver of one fish, and for whole shrimps and oysters.

Acknowledgment: The technical assistance of Messrs. P. M. Connor and M. J. WARDLE in carrying cut many of the toxicity experiments is gratefully acknowledged.

\section{LITERATURE CITED}

Butler, P. A., 1966. The problem of pesticides in estuaries. Spec. Publ. Am. Fish. Soc. No 3 , $110-115$.

D.S.I.R., 1961. Synthetic detergents. Notes Wat. Pollut. No. 15.

Faubert Maunder, M. J. de, Egan, H., Godly, E. W., Hammond, E. W., Roburn, J. \& Thomson, J., 1964. Clean-up of animal fats and dairy products for the analysis of chlorinated pesticide residues. Analyst, Lond. 89, 168-174.

Holden, A. V., 1966. Organo-chlorine insecticide residues in salmonid fish. J. appl. Ecol. 3 (Suppl.), 45-53.

Marchetti, R., 1965. Critical review of the effects of synthetic detergents on aquatic life. Stud. Rev. gen. Fish. Coun. Mediterr. No 26.

Ministry of Technology, 1966. Synthetic detergents. II: non-ionic detergents. Notes Wat. Pollut. No 34.

Moss, H. V., 1958. Synthetic detergents. Continuing research related to water and sewage treatment. Wat. \& Wat. Engng. 61 (745), 116-119.

Robinson, J., Coulson, J. C., Crabtree, A. N., Potts. G. R. \& Richardson, A., 1967. Organo-chlorine residues in marine organisms. Nature, Lond. 214 (5095), 1307-1311.

ToDd, R., 1954. Water purification upset seriously by detergents. Wat. Sewage Wks 101 (2), 80.

\section{Dicussion following the paper by PORTMANN ${ }^{1}$}

Kinne: I am glad that Dr. Portmann has studied toxicity of pollutants as a function of different important parameters, namely, temperature, size of the test animal, and starvation. A detailed assessment of toxicity is, no doubt, only possible if different physiological states of the organism in question and different environmental conditions are taken into account. My question: Have you done or are you planning to conduct any experiments on the efficiency of food conversion? It seems to me that caloric analyses - including uptake, conversion, and excretion of food - represent a most useful and important criterion for the assessment of the economy of life processes under different stresses of pollution.

Simpson: We do consider such studies important, but at the moment we are pressing ahead with the general review of the toxicity of a range of substances and with examining some of the effects of other factors on these. With our limited staff $I$ think we have to limit our research to this for the present.

1 The paper was presented at the Symposium by Mr. A. C. Simpson, Burnham on Crouch. 
Mann: Bisher wurde nur über die Wirkung einzelner Stoffe auf Fische etc. berichtet. Bei den Abwässern der Industrie haben wir es aber nicht mit definierten Einzelsubstanzen, sondern mit Stoffgemischen zu tun. Ich halte es daher für unbedingt notwendig, Kombinationen von Abwasserstoffen zu untersuchen. Aus der Abwasserchemie des Süßwassers ist bekannt, daß manche Stoffe in Kombinationen additiv wirken; andere rufen sogar noch stärkere Wirkungen hervor, als aus ihrer Addition zu erwarten wäre.

SIMPSON: I agree that it is most important to examine the toxicity of mixtures of toxicants; it is planned to include them in the near future.

KINNE: Ein Wort zu der eben von Herrn Kollegen MANN erwähnten additiven biologischen Wirkung mancher Abwasserinhaltsstoffe. Dieses Phänomen wurde während des Symposiums verschiedentlich angesprochen. Es ist sicher von grundlegender Bedeutung, vor allem wenn es darum geht, die unter definierten Laboratoriumsbedingungen erarbeiteten Versuchsergebnisse auf die Situation im Meer zu übertragen und Vorhersagen über das Ausmaß der jeweils zu erwartenden biologischen Konsequenzen der Einleitung bestimmter Substanzgemische zu machen. Brauchbare Voraussagen dieser Art sind ja ein Hauptziel unserer gegenwärtigen $\mathrm{Ab}-$ wasserforschung. - Abwasserinhaltsstoffe können sich aber nicht nur hinsichtlich ihrer biologischen Wirkungen beeinflussen, sondern auch "direkt" durch physiko-chemische Wechselwirkungen. Es erscheint mir daher wichtig, daß derartige Interreaktionen zwischen Abwasserkomponenten untersucht werden. Dies ist natürlich ein Aspekt der Abwasserforschung, der weniger den Biologen als den Wasserchemiker angeht. Aber auch bei primär biologisch orientierten Untersuchungen darf dieser Aspekt nicht völlig ausgeklammert werden, weil beispielsweise ein an Ort A eingebrachter (und vom Biologen hinsichtlich seiner physiologischen und ökologischen Wirkungen untersuchter) Stoff schon an einem wenige Kilometer entfernten Ort B seine chemische Identität verändert haben und zu einem Stoff mit anderen biologischen Konsequenzen geworden sein könnte.

Pearson: Could I ask you if you have investigated the level of pesticide residues in Ammodytes species? There was a suggestion that the increased level of pesticide residues in the eggs of certain sea-bird species was related to the level of such substances in Ammodytes spec. which constitute their major food source.

Simpson: No, we have not yet included Ammodytes in our pesticide analyses. 